\title{
Effect of Macro Nutrients and Nano-Boron Foliar Application on Vegetative Growth, Yield and Fruit Quality of Manzanillo Olive
}

\author{
Mohamed A. Hussein ${ }^{1}$ and EmadEldin H.Abd-Elall ${ }^{1}$
}

\begin{abstract}
This study was conducted during three successive growing seasons of 2015, 2016 and 2017, in the experimental farm, faculty of Agriculture, Al kawamell, Sohag University, Egypt, to evaluate the efficiency of foliar by macro nutrients at 2.5 to $7.5 \mathrm{~g} / \mathrm{L}$ and / or nano-boron at 0.025 to $0.1 \%$ on fruiting buds \%, growth, yield and fruit quality of 'Manzanillo' olive grown in sandy soil. These nutrients were sprayed individually or combined together three times during the growing season; $1^{\text {st }}$ week of Jan, 1stweek of March, and $1^{\text {st }}$ week of May. Single and combined applications of macro nutrients at 2.5 to $7.5 \mathrm{~g} / \mathrm{L}$ and nano-boron at 0.025 to $0.1 \%$ had stimulated the vegetative growth, shoot length, leaf area and number of leaves, percentage of $N, P, K$ and $B$ in leaves, fruiting buds $\%$, yield, fruit weight and dimensions and fruit oils \% compared to the control. The promotion on these parameters was associated with increasing concentrations of both applied nutrients. The effect of using macro nutrients was significantly higher than nano-boron $\%$ in this respect. Combined applications were also better than using each material alone when carrying out three sprays at the $1^{\text {st }}$ week of Jan and , $1^{\text {st }}$ week of March, and $1^{\text {st }}$ week of May. The mixture of macro nutrients at $5 \mathrm{~g} / \mathrm{l}$ and nanoboron at $0.1 \%$ gave the best results with regard to yield and fruit quality of Manzanillo olive.
\end{abstract}

Keywords: Manzanillo olive trees, growth, fruiting buds, yield, fruit quality, macro nutrients, nano-boron.

\section{INTRODUCTION}

Olive is considered one of the most important fruit crops in Egypt. The total acreage subjected to olive growing reached about 160157 fed. ,(69633 hc.), with total production of about 694309 ton fruits (FAO 2016). Around $30 \%$ of this area is grown in the newly reclaimed lands. The Spanich cv. Manzanillo is the most important commercial variety in the world (Hartmann and Papaioannou, 1971). Manzanillo is an early ripening cultivar and a heavy bearer, used for table olives and for oil production (Bailey, 1961).

Under sandy soil conditions, olive plants suffer from deficiency of macro and micro nutrients. Growing olive trees under such condition weakling tree growth and consequently reduce its productivity. Therefore, recent studies prefer to stimulate the growth of olive trees foliar application of some nutrients can be used. These elements play an important role in stimulating growth and fruiting, moreover stimulating bio-synthesis through the accumulation of nutrients and hormones (Nijjar, 1985).

It is considered that using macro nutrients very essential for plant growth and development as reported by (Ferreira, 1984) who found that different macro nutrients had significant influence on olive various growth aspects of olive tree. It is known that foliar application does not totally substitute soil applied fertilizer but it does help increasing the uptake and promote the efficiency of the nutrients applied to the soil. This application technique is especially important for micronutrients while macronutrients foliar sprays have not been recommended, because these elements are needed in high quantities and leaves uptake is not sufficient to supply them (Christensen, 2005). However, major nutrients can be used because the amount applied at any time is small and thus it requires several applications to meet the needs of a crop. The increased efficiency reduces the need for soil applied fertilizers and leaching/run-off of nutrients as well as to reduce the impact of chemicals fertilizer on the environment. (Venugoplan et al., 1995;Dong et al., 2005; Rezk et al.,2008).

Boron is a micronutrient that plays an important role in growth behavior and productivity of fruit trees. It increases pollen grains germination and pollen tube elongation, as well as fruit set percentage (Tsalidas et al., 1994). Moreover, previous studies indicated that boron foliar application significantly influenced the survival of 'Manzanillo' and 'Picual' olive cultivars and increased the tree growth and yield (Maksoud et al., 2004;Eassa, 2000).

Applying foliar treatment of macro nutrients and nano-boron is promising treatments that have influenced growth and production of trees. Thus the objective of this study was to examine the effect of foliar spray of macro nutrients and / or nano-boron on the growth, leaf mineral content, yield and fruit quality of 'Manzanillo' olive growing in sandy soil.

\section{MATERIALS AND METHODS}

This study was conducted during 2015, 2016 and 2017 seasons on 30 trees of Manzanillo olive cultivar. The trees were about 15- years old and are growing in

\footnotetext{
${ }^{1}$ Horticulture Department, Faculty of Agriculture, Sohag University, Sohag, Egypt.

E-Mail: kkk9932001@yahoo.co.uk

Received June 26, 2018, Accepted August 01, 2018
} 
the experimental farm, faculty of Agriculture, Al kawamell, Souhag University, Egypt. Evaluation of the effect of foliar application of Macro nutrients (19-1919+1 N.P.K-Mg, Shoura chemicals Co.) and Nanoboron on fruiting buds \%, growth, yield and fruit quality of 'Manzanillo' olive trees were investigated. Olive trees are planted at $5 \times 5$ meter apart (168 tree/fed.) in sandy soil using drip irrigation system. All agricultural practices were done regularly for the trees.

Soil analysis was done according to Black (1965)

Table 1. The main physical and chemical properties of the tested soil

\begin{tabular}{lc}
\multicolumn{1}{c}{ Content } & Value \\
\hline Sand \% & 76 \\
Silt \% & 12.0 \\
Clay \% & 12.0 \\
Texture grade & Sandy \\
pH( $1: 2.5$ extract) & 7.35 \\
EC ( 1: 2.5 extract) $\mathrm{dsm}^{-1}$ ) & 2.5 \\
Calcium carbonate \% & 3.22 \\
Total N\% & 0.008 \\
Available P ( Olsen, $\mathrm{mg} \mathrm{kg}^{-1}$ ) & 2.1 \\
Available K ( ammonium acetate , & 92.4 \\
mg kg & \\
\hline
\end{tabular}

\section{This experiment included ten treatments:}

1. Control (sprayed with water only)

2. Spraying macro nutrients at $2.5 \mathrm{~g} / \mathrm{l}$

3. Spraying macro nutrients at $5 \mathrm{~g} / \mathrm{l}$

4. Spraying macro nutrients at $10 \mathrm{~g} / \mathrm{l}$

5. Spraying nano-boron at $0.025 \%$

6. Spraying nano-boron at 0.5

7. Spraying nano-boron at $0.1 \%$

8. Spraying (macro nutrients at $2.5 \mathrm{~g} / \mathrm{l}+$ nano-boron at $0.025 \%)$.

9. Spraying (macro nutrients at $5 \mathrm{~g} / \mathrm{l}+$ nano-boron at $0.5)$.

10. Spraying (macro nutrients at $7.5 \mathrm{~g} / \mathrm{l}+$ nano-boron at $0.1 \%)$.

Each treatment was replicated three times, two tree per each. Macro nutrients and nano-boron were sprayed three times at the $1^{\text {st }}$ week of Jan. the $1^{\text {st }}$ week of March. and the $1^{\text {st }}$ week of May. Triton B as agent was added to all spraying solutions at $0.05 \%$ and spraying was done till run off.

During the three seasons the following parameters were recorded:

1- Percentage of fruiting buds.

2- Vegetative growth characteristics such as main shoot length, number of leaves per shoot and leaf area (Ahmed and Morsy, 1999).
3- Amount of $\mathrm{N}, \mathrm{P}$ and $\mathrm{K}$ and $\mathrm{B}\left(\mathrm{mg} \mathrm{kg}^{-1}\right)$ on dry weight basis was recorded in the twenty leaves

4- Yield and number of fruits per tree (in the middle of October).

5- Physical and chemical characteristics of the fruits such as fruit weight and dimensions, flesh/stone ratio and fruit oil percentage were determined (A.O.A.C., 2000)

Statistical analysis was done using ANOVA followed by L.S.D at $5 \%$ to compare the differences between treatments means according to Mead et al., ( 1993)

\section{The percentage of fruiting buds}

Table (2) showed that the percentage of fruiting buds was significantly increased in response to a single and combined of macro nutrients treatments (2.5 to 7.5 $\mathrm{g} / \mathrm{l})$ and nano-boron $(0.025$ to $1 \%)$ compared to the control treatment. The promotion on fruiting buds percentage was significantly associated with using macro nutrients than using nano-boron. There was a gradual stimulation on fruit buds \% with increasing concentrations of macro nutrients from 2.5 to $7.5 \mathrm{~g} / \mathrm{l}$ and nano-boron from 0.025 to $1 \%$. While there was no significant effect on fruiting buds \% with treatments of macro nutrients at $2.5 \mathrm{~g} / \mathrm{l}$ and nano-boron at $0.025 \%$ compared to the control treatment. Combined applications were significantly favourable than using each elements alone in this respect. No significant differences were found within treatments of macro nutrients at5 $\mathrm{g} / \mathrm{l}+$ nano-boron at $0.5 \%$ and (Macro nutrients at $7.5 \mathrm{~g} / \mathrm{l}+$ nano-boron at $1 \%$ ) on fruiting buds $\%$, therefore, it is recommended to use Macro nutrients at $5 \mathrm{~g} / \mathrm{l}+$ nano-boron at $0.5 \%$ for promoting fruiting buds $\%$. The highest values of fruiting buds reached $73.1,50.0$ and $78.0 \%$ while the control trees produced 59.8, 35.9 and $55.8 \%$ fruiting buds, for the three seasons, respectively. These results coincided with (Rai and Tewari, 1988;Osman and Abo-Taleb, 1999; Eassa, 2000 \& 2006;El- Khawaga, 2007).

\section{Growth characteristics:}

Table (3) revealed that all treatment spraying with macro nutrients at $(2.5$ to $7.5 \mathrm{~g} / \mathrm{l})$ and nano-boron at $(0.025$ to $1 \%)$ significantly stimulated shoot length (except macro nutrients at $2.5 \mathrm{~g} / \mathrm{L}$, nano-boron at $0.025 \%$ and nano-boron at),number of leaves/shoot(except Macro nutrients at $2.5 \mathrm{~g} / \mathrm{L}$ in the first season) and leaf area(excepted Macro nutrients at $2.5 \mathrm{~g} / \mathrm{L}$ in three seasons) compared to the control. Using macro nutrients at $(2.5$ to $7.5 \mathrm{~g} / \mathrm{l})$ significantly was superior to using nano-boron at (0.025 to $1 \%)$ in 
Table 2. Effect of foliar application of macro nutrients and nano-boron on fruiting buds, Main shoot length, number of leaves/shoot and leaf area of Manzanillo olive trees during2015, 2016 and 2017 seasons Fruiting buds \% Main shoot length No. of leaves/shoot $\quad$ Leaf area $(\mathrm{cm} .)^{2}$

Treatment (cm.)

\begin{tabular}{|c|c|c|c|c|c|c|c|c|c|c|c|c|}
\hline & 2015 & 2016 & 2017 & 2015 & 2016 & 2017 & 2015 & 2016 & 2017 & 2015 & 2016 & 2017 \\
\hline Control & 508 & 350 & 558 & 130 & 15.0 & 14.2 & 11.8 & 128 & 11.2 & 5.08 & 5.11 & 5.14 \\
\hline $\begin{array}{l}\text { Spraying N P K at } 2.5 \\
\text { g/L }\end{array}$ & 61.2 & 36.9 & 57.0 & 13.5 & 15.9 & 15.4 & 10.9 & 13.2 & 12.2 & 5.00 & .10 & .24 \\
\hline Spraying N P K at $5 \mathrm{~g} / \mathrm{L}$ & 65.5 & 43.5 & 66.0 & 14.3 & 16.6 & 16.8 & 13.5 & 13.6 & 13.5 & 5.21 & 5.31 & 5.33 \\
\hline $\begin{array}{l}\text { Spraying N P K at } 7.5 \\
\text { g/L }\end{array}$ & 65.4 & 44.0 & 68.3 & 15.0 & 16.7 & 17.8 & 14.2 & 13.9 & 13.7 & 5.26 & 5.21 & 5.31 \\
\hline $\begin{array}{l}\text { Spraying Nano-boron at } \\
0.025 \%\end{array}$ & 60.5 & 35.0 & 56.4 & 13.7 & 15.6 & 15.0 & 14.6 & 12.9 & 13.9 & 5.31 & 5.41 & 5.50 \\
\hline Nano-boron at & 62.7 & 37.5 & 59.2 & 14.4 & 16.0 & 16.1 & 12.3 & 12.8 & 12.8 & 5.36 & 5.42 & 5.51 \\
\hline ng Nano-boron at & 63.5 & 38.0 & 65.3 & 14.8 & 16.3 & 16.4 & 12.4 & 13.1 & 12.5 & 5.41 & 5.43 & 5.42 \\
\hline $\begin{array}{l}\text { Macro at } 2.5 \mathrm{~g} / \mathrm{L}+\text { Nano- } \\
\text { boron at } 0.025 \%\end{array}$ & 66.4 & 49.0 & 75.0 & 15.0 & 16.5 & 17.2 & 12.5 & 13.2 & 12.9 & 5.51 & 5.59 & 5.60 \\
\hline $\begin{array}{l}\text { at } 5 \mathrm{~g} / \mathrm{L}+\text { Nano- } \\
\text { at } 0.5 \%\end{array}$ & 71.4 & 50.0 & 78.0 & 16.6 & 17.9 & 18.6 & 15.2 & 14.2 & 14.5 & 5.66 & 5.64 & 5.70 \\
\hline $\begin{array}{l}\text { Macro at } 5 \mathrm{~g} / \mathrm{L}+\text { Nano- } \\
\text { boron at } 1 \%\end{array}$ & 73.2 & 50.3 & 78.4 & 17.0 & 19.3 & 18.8 & 15.3 & 14.3 & 14.6 & 5.67 & 3.65 & 5.71 \\
\hline New L.S.D. at 5\% & 2.0 & 2.1 & 2.2 & 1.2 & 1.4 & 1.3 & 0.2 & 0.2 & 2.0 & 0.07 & 0.06 & 0.08 \\
\hline
\end{tabular}

Table 3. Effect of foliar application of macro nutrients and nano-boron on percentages of $n, p$, $k$ and $b$ content in the leaves of manzanillo olive trees during2015, 2016 and 2017 seasons

\begin{tabular}{|c|c|c|c|c|c|c|c|c|c|c|c|c|}
\hline \multirow{2}{*}{ Treatment } & \multicolumn{3}{|c|}{$\mathbf{N} \%$} & \multicolumn{3}{|c|}{$\mathbf{P} \%$} & \multicolumn{3}{|c|}{ K \% } & \multicolumn{3}{|c|}{ Leaf $B\left(\mathrm{mg} \mathrm{kg}^{-1}\right)$} \\
\hline & 2015 & 2016 & 2017 & 2015 & 2016 & 2017 & 2015 & 2016 & 2017 & 2015 & 2016 & 2017 \\
\hline Control & 1.40 & 1.50 & 1.46 & 0.115 & 0.119 & 0.120 & 1.09 & 1.11 & 1.12 & 22.9 & 23.5 & 23.7 \\
\hline $\begin{array}{l}\text { Spraying Macro at } 2.5 \\
\mathrm{~g} / \mathrm{L}\end{array}$ & 1.50 & 1.53 & 1.60 & 0.126 & 0.130 & 0.132 & 1.25 & 1.19 & 1.27 & 23.5 & 23.8 & 24.6 \\
\hline $\begin{array}{l}\text { Spraying Macro at } 5 \\
\mathrm{~g} / \mathrm{L}\end{array}$ & 1.51 & 1.56 & 1.63 & 0.126 & 0.133 & 0.135 & 1.25 & 1.22 & 1.28 & 23.8 & 24.2 & 24.2 \\
\hline $\begin{array}{l}\text { Spraying Macro at } 7.5 \\
\mathrm{~g} / \mathrm{L}\end{array}$ & 1.58 & 1.59 & 1.67 & 0.130 & 0.134 & 0.136 & 1.29 & 1.23 & 1.30 & 23.6 & 23.0 & 24.3 \\
\hline $\begin{array}{l}\text { Spraying Nano-boron } \\
\text { at } 0.025 \%\end{array}$ & 1.45 & 1.55 & 1.61 & 0.119 & 0.121 & 0.119 & 1.13 & 1.13 & 1.13 & 24.3 & 25.1 & 25.4 \\
\hline $\begin{array}{l}\text { Spraying Nano-boron } \\
\text { at } 0.5 \%\end{array}$ & 1.49 & 1.56 & 1.58 & 0.120 & 0.124 & 0.123 & 1.15 & 1.19 & 1.15 & 25.6 & 26.0 & 25.7 \\
\hline $\begin{array}{l}\text { Spraying Nano-boron } \\
\text { at } 1 \%\end{array}$ & 1.50 & 1.58 & 1.60 & 0.122 & 0.124 & 0.120 & 1.14 & 1.15 & 1.19 & 26.5 & 27.1 & 27.1 \\
\hline $\begin{array}{l}\text { Macroat } 2.5 \mathrm{~g} / \mathrm{L}+\mathrm{Nano} \\
\text {-boron at } 0.025 \%\end{array}$ & 1.75 & 1.77 & 1.65 & 0.126 & 0.130 & 0.134 & 1.25 & 1.30 & 1.28 & 26.7 & 27.1 & 27.0 \\
\hline $\begin{array}{l}\text { Macro at } 5 \mathrm{~g} / \mathrm{L}+ \\
\text { Nano-boron at } 0.5 \%\end{array}$ & 1.78 & 1.80 & 1.83 & 0.130 & 0.135 & 0.135 & 1.30 & 1.39 & 1.37 & 27.1 & 27.1 & 27.9 \\
\hline $\begin{array}{l}\text { Macro at } 5 \mathrm{~g} / \mathrm{L}+ \\
\text { Nano-boron at } 1 \%\end{array}$ & 1.79 & 1.81 & 1.81 & 0.134 & 0.136 & 0.137 & 1.33 & 1.40 & 1.38 & 27.5 & 27.8 & 28.0 \\
\hline New L.S.D. at $5 \%$ & 0.08 & 0.06 & 0.07 & 0.004 & 0.004 & 0.005 & 0.04 & 0.04 & 0.05 & 0.4 & 0.4 & 0.5 \\
\hline
\end{tabular}


Increment concentrations of macro nutrients at $(2.5$ to $7.5 \mathrm{~g} / \mathrm{l})$ and nano-boron at $(0.025$ to $1 \%)$ failed to show significant promotion on these growth aspects. The maximum values were recorded on the trees received both materials macro nutrients at $(7.5 \mathrm{~g} / \mathrm{l})$ and nanoboron at $(1 \%)$. The lowest value of the main shoot length obtained by the control treatment. These results were true during three seasons. These positive effects of the treatments on vegetative growth were in agreement with (HU and Yang, 1982), (Fandi, 1987;Eassa, 2006) on boron.

\section{Percentages of $N, P, K$ and $B$ in the leaves:}

The content of Percentages of N, P, K and B in the leaves were significantly varied among the application of macro nutrients and/or nano-boron and the control treatment (Table 3 ). Treating the trees twice with macro nutrients at $(2.5$ to $7.5 \mathrm{~g} / \mathrm{l})$ and nano-boron at $(0.025$ to $1 \%)$ were not significant compared to the control treatment. Spraying the trees with Macro nutrients was significantly surpassed the application of nano-boron in stimulating these nutrients, while combined applications of Macro nutrients and nano-boron significantly enhanced these nutrients than using each material alone. Increasing concentrations of macro nutrients from $(2.5$ to $7.5 \mathrm{~g} / \mathrm{l})$ and nano-boron from $(0.025$ to $1 \%)$ had no significant promotion on these nutrients. The maximum $\mathrm{N}(1.79,1.81 \& 1.81 \%) ; \mathrm{P}(0.134,0.136 \& 0.137 \%), \mathrm{K}$ $(1.33,1.40 \& 1.38 \%)$ and $\mathrm{B}\left(27.5,27.8 \& 28.0 \mathrm{mg} \mathrm{kg}^{-1)}\right.$ were recorded on the trees sprayed with macro nutrients and nano-boron at the high concentration compared to the control.. These results were noticeable during three seasons. As for the reduction in leaf $\mathrm{P}$ content might be attributed to the antagonism between Fe and P (Nawar, 1991). These results agreed to some extent with those of (Eassa, 2000 and 2006; Chatzissavvids, 2004; Maksoud et al., 2004;El-Seginy et al., 2003;Abd-Ella et al., 2006).

Davarpanah et al. (2016) indicated that the foliar application of nano-Zn and nano-B fertilizers in pomegranate increased the leaf concentrations of both microelements, reflecting the improvements in tree nutrient status.

\section{The yield:}

Table 4 revealed that treating the trees with macro nutrients and/or nano-boron was significantly very effective in enhancing yield in terms of increasing weight, height and diameter of fruit compared to the control treatment. The promotion was significantly related to the increase in concentrations of both macro nutrients and nano-boron. Increasing concentrations of macro nutrients from 2.5 to $7.5 \mathrm{~g} / \mathrm{l}$ and nano-boron from 0.025 to $1 \%$ had negligible promotion on yield. Using macro nutrients from 2.5 to $7.5 \mathrm{~g} / \mathrm{l}$ significantly improved yield than using nano-boron from 0.025 to 1 $\%$. Using both elements together was significantly better than using each element alone in improving the yield. The best results with regard to the yield from economical point of view were obtained due to treating the trees with macro nutrients plus nano-boron $(7.5 \mathrm{~g} / \mathrm{l}$ for macro nutrients and $1 \%$ for nano-boron) compared to control. Similar results were found during the three seasons. Increased in yield might be due to more fruit set, larger fruit and more fruit weight, because of the role of boron on cell division and cell enlargement and the volume of intercellular spaces in mesocarpic cells increased. Also this phenomenon was related to very high mobility of photosynthetates in developing fruits that are active and strong sinks (Perica, et al 2001). The reduction in leaf $\mathrm{P}$ content might be attributed to the antagonism between $\mathrm{Fe}$ and P (Nawar, 1991). These results agreed to some extent with those of (Eassa, 2000 and 2006;Chatzissavvids, 2004;Maksoud et al., 2004;El-Seginy et al., 2003).

\section{Fruit quality:}

Table 4and 5 revealed that treating the olive trees with macro nutrients and/or nano-boron was significantly enhanced fruit quality in terms of increasing weight, height and diameter of fruit, flesh/stone and fruit oil \% compared to the control treatment. The promotion was significantly increased as concentrations increased of both Macro nutrients and nano-boron. Increasing concentrations of macro nutrients from 2.5 to $7.5 \mathrm{~g} / \mathrm{l}$ and nano-boron from 0.025 to $1 \%$ had no significant promotion on fruit quality. Using macro nutrients from 2.5 to $7.5 \mathrm{~g} / 1$ significantly improved fruit quality compared to nano-boron from 0.025 to $1 \%$. Using both element together was significantly preferable than using each element alone in improving fruit quality. The best results with regard to fruit quality were obtained after treating the trees with macro nutrients plus nano-boron at $(5 \mathrm{~g} / \mathrm{l}$ for macro nutrients and $1 \%$ for nano-boron) compared to the control.

Similar results were announced during the three seasons. The beneficial effect of these nutrients in synthesis of various organic foods and activating both cell division and cell enlargement (Nijjar, 1985) could explain the positive influence of such elements on growth and development of fruits. These results are in accordance with those obtained by (Hanson, 1991;Eassa, 2000 and 2006; Chatzissavidis et al., 2004;El-Khawaga, 2007). 
Table 4.Effect of foliar application of macro nutrients and nano-boron on the yield, fruit weight, fruit diameter and fruit height of the fruits of manzanillo olive trees during 2016 and 2017 seasons

\begin{tabular}{|c|c|c|c|c|c|c|c|c|c|c|c|c|}
\hline \multirow{2}{*}{ Treatment } & \multicolumn{3}{|c|}{ Yield/tree (kg) } & \multicolumn{3}{|c|}{ Fruit weight (g) } & \multicolumn{3}{|c|}{ Fruit diameter $(\mathrm{cm})$} & \multicolumn{3}{|c|}{ Fruit height $(\mathrm{cm})$} \\
\hline & 2015 & 2016 & 2015 & 2016 & 2015 & 2016 & 2015 & 2016 & 2017 & 2015 & 2016 & 2017 \\
\hline Control & 20.8 & 15.2 & 22.6 & 4.2 & 4.8 & 4.5 & 1.81 & 2.02 & 1.85 & 2.25 & 2.4 & 2.3 \\
\hline $\begin{array}{l}\text { Spraying Macro at } 2.5 \\
\mathrm{~g} / \mathrm{L}\end{array}$ & 22.4 & 17.2 & 23.4 & 4.5 & 5.1 & 5.2 & 1.83 & 2.04 & 1.89 & 2.32 & 2.43 & 2.33 \\
\hline $\begin{array}{l}\text { Spraying Macro at } 5 \\
\mathrm{~g} / \mathrm{L}\end{array}$ & 24.5 & 18.4 & 25.8 & 4.7 & 5.4 & 5.4 & 1.90 & 2.07 & 1.90 & 2.35 & 2.46 & 2.36 \\
\hline $\begin{array}{l}\text { Spraying Macro at } 7.5 \\
\mathrm{~g} / \mathrm{L}\end{array}$ & 26.5 & 18.7 & 26.5 & 5.6 & 6.5 & 5.9 & 1.96 & 2.13 & 1.99 & 2.40 & 2.47 & 2.37 \\
\hline $\begin{array}{l}\text { Spraying Nano-boron at } \\
0.025 \%\end{array}$ & 23.1 & 16.8 & 25.2 & 4.4 & 5.1 & 5.2 & 1.85 & 2.10 & 1.90 & 2.39 & 2.50 & 2.40 \\
\hline $\begin{array}{l}\text { Spraying Nano-boron at } \\
0.5 \%\end{array}$ & 24.3 & 17.6 & 23.1 & 5.2 & 6.1 & 5.9 & 1.92 & 2.12 & 1.92 & 2.41 & 2.53 & 2.43 \\
\hline $\begin{array}{l}\text { Spraying Nano-boron at } \\
1 \%\end{array}$ & 25.1 & 18.2 & 24.5 & 5.6 & 6.4 & 6.1 & 1.93 & 2.13 & 1.93 & 2.42 & 2.54 & 2.44 \\
\hline $\begin{array}{l}\text { Macro at } 2.5 \mathrm{~g} / \mathrm{L}+ \\
\text { Nano-boron at } 0.025 \%\end{array}$ & 24.3 & 17.2 & 26.4 & 5.8 & 6.6 & 6.3 & 1.96 & 2.15 & 1.95 & 2.46 & 2.57 & 2.47 \\
\hline $\begin{array}{l}\text { Macro at } 5 \mathrm{~g} / \mathrm{L}+\text { Nano- } \\
\text { boron at } 0.5 \%\end{array}$ & 27.2 & 18.6 & 27.4 & 6.1 & 7.1 & 6.4 & 2.07 & 2.27 & 2.11 & 2.49 & 2.6 & 2.5 \\
\hline $\begin{array}{l}\text { Macro at } 5 \mathrm{~g} / \mathrm{L}+\text { Nano- } \\
\text { boron at } 1 \%\end{array}$ & 27.5 & 18.8 & 27.8 & 6.2 & 7.2 & 6.4 & 2.11 & 2.25 & 2.13 & 2.50 & 2.61 & 2.51 \\
\hline New L.S.D. at $5 \%$ & 1.08 & 0.85 & 1.09 & 0.7 & 0.6 & 0.8 & 0.02 & 0.02 & 0.02 & 0.02 & 0.02 & 0.02 \\
\hline
\end{tabular}

Table 5. Effect of foliar application of macro nutrients and nano-boron on fruit oil percentage and flesh/stone of the fruits of manzanillo olive trees during 2016 and 2017 seasons

\begin{tabular}{lcccccc}
\hline \multicolumn{1}{c}{ Treatment } & \multicolumn{2}{c}{ Fruit oil percentage (\%) } & \multicolumn{3}{c}{ Flesh/stone } \\
\cline { 2 - 7 } & $\mathbf{2 0 1 5}$ & $\mathbf{2 0 1 6}$ & $\mathbf{2 0 1 5}$ & $\mathbf{2 0 1 6}$ & $\mathbf{2 0 1 5}$ & $\mathbf{2 0 1 6}$ \\
\hline Control & 18.9 & 19.9 & 18.6 & 2.650 & 2.49 & 2.44 \\
Spraying Macro at $2.5 \mathrm{~g} / \mathrm{L}$ & 18.9 & 20.4 & 18.7 & 2.55 & 2.56 & 2.50 \\
Spraying Macro at 5 g/L & 19.2 & 20.0 & 18.9 & 2.60 & 2.59 & 2.55 \\
Spraying Macro at 7.5 g/L & 19.3 & 20.0 & 19.2 & 2.61 & 2.60 & 2.55 \\
Spraying Nano-boron at 0.025 \% & 19.7 & 19.5 & 18.8 & 2.66 & 2.66 & 2.70 \\
Spraying Nano-boron at 0.5 \% & 19.1 & 20.2 & 18.8 & 2.71 & 2.69 & 2.65 \\
Spraying Nano-boron at 1 \% & 19.3 & 20.1 & 19.1 & 2.72 & 2.72 & 2.70 \\
Macro at 2.5g/L+ Nano-boron at 0.025 \% & 19.5 & 20.2 & 19.2 & 2.77 & 2.78 & 2.73 \\
Macro at 5 g/L+ Nano-boron at 0.5 \% & 19.8 & 20.6 & 19.5 & 2.80 & 2.82 & 2.75 \\
Macro at 5 g/L+ Nano-boron at 1 \% & 19.5 & 20.7 & 19.7 & 2.81 & 2.83 & 2.79 \\
New L.S.D. at 5\% & 0.2 & 0.3 & 0.2 & 0.03 & 0.03 & 0.03 \\
\hline
\end{tabular}

\section{CONCLUSION}

Carrying out three foliar sprays at the $1^{\text {st }}$ week of Jan, the $1^{\text {st }}$ week of March, and the $1^{\text {st }}$ week of May by a mixture of macro nutrientsat7.5 $\mathrm{g} / \mathrm{l}$ and nano-boron at 1 $\%$ gave the best results with regard to yield and fruit quality of Manzanillo olive grown in sandy soil.

\section{REFERENCES}

Ahmed, F. F. and M. H. Morsy. 1999. A new method for measuring leaf area in different fruit crops. Minia of Agric. Res. \& Develop. .19: 97-105.
Association of Official Agricultural Chemists, 2000. Official Methods of Analysis (A.O.A.C), 12th Ed., Benjamin Franklin Station, Washington D.Q, U.S.A. pp: 490-510.

Bailey, L.H. 1961. The standard Cyclopedia of Horticulture. Vol. 11: 1414-1415.

Black, C.A. 1965. Methods of Soil Analysis. Amer. Soc. of Agron., Madison, Wisconsin, U.S.A. pp: 1 - 20.

Chatzissavvidis, C. A., I.N. Therios and C. Antonopoulou. 2004. Seasonal variation of nutrient concentration in two olive (Oleaee uropaea L.) Svs. irrigated with high boron water. Lab. Of Pom., School of Agric. Aristotle, Univ., 54124 Thessaloniki, Greece. 
Christensen, L. P. 2005. Foliar fertilization in vine programs, p. 83-90. In: Christensen, L.P. and D.R. Smart (eds.). Proc. of the Soil Environment and Vine Mineral Nutrition Symposium. American Society for Enology andViticulture, Davis, CA.

Davarpanah,S., A.Tehranifar, G. Davarynejad, J. Abad?a, and R.Khorasani.2016.Effectsoffoliarapplicationsofzincandbor onnano- fertilizerson pomegranate (Punica granatum cv.Ardestani) fruit yield and quality. Sci. Hortic. $210: 57-$ 64.

Dong, S., D. Neilsen, G. H. Neilsen and L. H. Fuchigami, 2005. Foliar N application reduces soil NO $-\mathrm{N}$ leaching loss in apples orchards. PlantSoil. 268: 357-366.

Eassa K. B. 2000. Physiological studies on nutritional status and productivity of olive trees under new land condition. Ph.D. Distribution, Fac. Agric. Moshtohor, Univ. of Zagazig, Egypt.

Eassa K. B. 2006. Effect of boron fertilization on growth and productivity of Aggizi olive trees grown in sandy soils. Alex. J. Agric. Res (51):67-73.

El-Khawaga, A. S. 2007. Improving growth and productivity of Manzanillo olive trees with foliar application of some nutrients and girdling under sandy soil. J. Applied Science Research, 3 (9):818-822.

El-Seginy, Amal M., Malaka, S. M. Naiema, W. M. Abd ElMesseih and G. I. Eliwa. 2003. Effect of foliar spray of some micronutrients and gibberellin on leaf mineral content, fruit set, yield and fruit quality of Anna apple trees. Alex. J. Agric. Res. 48 (3):137-143.

Fandi, N. M. 1987. Effect of foliar fertilization, chemical fruit thinning and supplemental irrigation on growth and fruiting of the "Nabali" olive cv. Dirasat. 14 (2):177-178.

FAO., 2016. Agricultural Statistics of the Food and Agriculture Organization of the United Nations, Rome.

Ferreira, J., A. Garc?a-Ortiz, , L. Fr?as and A. Fern?ndez. 1984. Los nutrientes N, P, K en la fertilizaci?n del olivar Ferreira, In: X Aniversario Red Cooperativa Europea de Investi- gaci?n en Oleicultura, C?rdoba, Spain.

Hartmann, H. T. and P. Papaioannou.1971. Olive varieties in California. Calif. Agric. Exp. Stn. Bult. 720.
HU, Q. H. and M. G. Yang. 1982. Preliminary studies on the symptoms of boron deficiency on (Oleae europeae L.). Plant Physiol. No. 53:14-17(Hort.Abst.53:9016).

Maksoud, M. A., A. F. Amera, H. K. Fekria and F. H. Laila. 2004. Effect of boron fertilization on growth, yield and quality of olives. Arab. Univ. J. Agric. Sci.12 (1) :361 369.

Mead, R., R. N. Curnow, and A. M. Harted. 1993. Statistical methods in Agricultural and Experimental Biology. 2nd Ed. Chapman \& Hall, London pp. 10-44.

Nawar, A. 1991. Some physiological and biochemical aspects of leaf iron chlorosis in Anna trees.1-Leaf iron fraction, mineral composition and activity of peroxidase and catalase enzymes. Alex. J. Agric. Res. 36 (2)103-114.

Nijjar, G. S. 1985. Nutrition of fruit tree, ushara jiku markala puplisher new -delhi, India, pp:10-50.

Osman, L. H. and A. Abo-Taleb-Safia. 1999. Effect of mineral fertilization levels of nitrogen, phosphorus and potassium and boron sprays on growth of olive trans plants. Minufiya J. Agric. Res. 24(1): 237-250.

Perica, S., P. H. Brown, J. H. Connel, A. M. S. Nyomora, C. Dordas, $\mathrm{H}$. $\mathrm{Hu}, 2001$. Foliar boron application improves flower fertility and fruit set of olive. Hort Sci. 36(4):714716.

Rai, R. M. and J. D. Tewari. 1988. Yield contributing factors as influenced by micro-nutrient sprays in orange. Progressive Hort. 20:124- 127.

Rezk, A.I., O.A . Nofal and A. B. El-Nasharty. 2008 . Improving yield and quality of some olive cultivars using an integrated and balanced fertilization program grown in calcareous soil . Alex. Sci. Exch. J.29: 217 - 222 .

Tsalidas, C. D., N. Yassoglou, C. S. Kosmas, and C. H. Kallianov, 1994. The availability of soil boron fractions to olive trees and barley and their relationship to soil properties. Plant Soil 162: 211-217.

Venugoplan, M.V., P. P. Tarhalkar and J. Singh.1995. Efficacy of phosphate carriers as foliar fertilizer on rain fed upland cotton (Gossypiumhirsutum). Indian J.Agric. Sci.65(5): 320-328. 


\section{الملخص العربي \\ تأثير الرش الورقي بالعناصر الكبرى والنانو بورن على النمو الخضرى والمحصول وجودة للزيتون المنز انيللو}

محمد احمد حسين حسن و عماد الدين حافظ عبدالعال

المئوية للزبت فى الثمرة مقارنة بمعاملة الكنترول. وكان التحسن فى هذه الصفات مرتبطا بزيادة التركيز المستخدم من هاتين المادتين وقد تفوق استخدام العناصر الكبرى عن هن باد

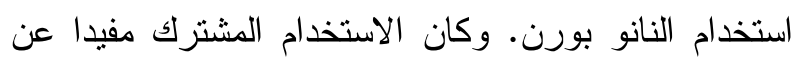
الاستخدام الفردى فى هذا الصدد.

وقد أمكن الحصول علي أفضل النتائج بخصوص كمية المحصول وخصائص الجودة فى أثجار الزيتون المنز انيللو

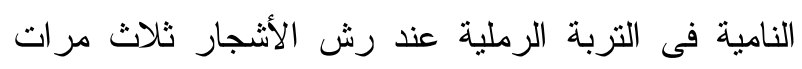
بمخلوط من العناصر الكبرى V, \% \% و النانو بورن بتركز \% ।

الكلمات الدالة: الزيتون المنزانيللو - النسبة المئوية للبر اعم الثمرية-النمو الخضرى- العناصر الغذائية الكبرى لئه لئون -المحصول - خصائص الجودة للثمار - النانو بورن
أجريت هذه الدراسة خلال ثلاث موسم زر اعية منتالية

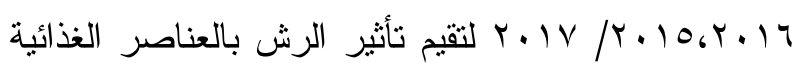
الكبرى بتركيز r,0 إلي V,o جم/لتر و النانو بورن بتركيز

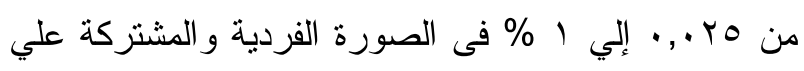
كل من النمو، النسبة المئوية للبراعم الثرية، الثرية كمية المحصول وخصائص الجودة للزيتون المنز انيللو النامية فى لئه التربة الرملية بمزرعة كلية الزراعة بمنطقة الكوامل-

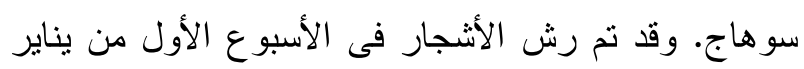

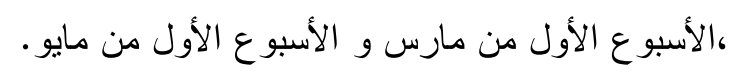
وتوضح النتائج تحسن ملحوظ فى طول النمو، عدد الأوراق علي النمو الواحد، مساحة الورقة، النسبة المئوية

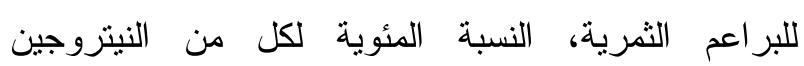

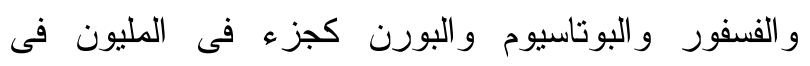
الورقة، كمية المحصول، وزن الثمرة و أبعادها و النسبة لئية 